\title{
Growth and Nutrient Concentration in Coffee Root System UNDER WeEd SPECIES COMPETITION ${ }^{1}$
}

\author{
Crescimento e Concentração de Nutrientes no Sistema Radicular do Cafeeiro sob Competição de \\ Plantas Daninhas
}

RONCHI, C.P. ${ }^{2}$, TERRA, A.A. ${ }^{3}$ e SILVA. A.A. ${ }^{4}$

\begin{abstract}
The effects of competition of six weed species on growth, nutrient concentration and nutrient content of coffee plant root system under greenhouse conditions were evaluated. Thirty days after coffee seedling transplantation into $12 \mathrm{~L}$ pots with soil level area of $6.5 \mathrm{dm}^{2}$. Weeds were transplanted or sowed in these pots, at densities of $0,1,2,3,4$ and 5 plants per pot. The duration of competition (or weedy periods) from weed transplantation or emergence until plant harvesting, at the weed preflowering stage, were (in days): 77 (Bidens pilosa), 180 (Commelina diffusa), 82 (Leonurus sibiricus), 68 (Nicandra physaloides), 148 (Richardia brasiliensis) and 133 (Sida rhombifolia). Dry matter of coffee plants was linearly reduced with increasing B. pilosa and S. rhombifolia density, with pronounced effect of B. pilosa. C. diffusa was the only weed species whose increasing density in the pots did not diminish crop root dry matter. $\boldsymbol{L}$. sibiricus, $\boldsymbol{N}$. physaloides and $\boldsymbol{R}$. brasiliensis reduced root dry matter of coffee plants by 75, 52 and 47\%, respectively, as compared to the weed-free treatment, regardless of weed density. Under competition, even though weed species showed lower macronutrient concentration in the roots (except for $P$ ), they accumulated $4.2(\mathrm{~N}), 12.3(\mathrm{P}), 4.3(\mathrm{~K}), 5.5(\mathrm{Ca}), 7.6(\mathrm{Mg})$ and $4.4(\mathrm{~S})$ times more nutrients in the roots than the coffee plants. Crop and weed nutrient concentration, as well as competition degrees greatly varied depending on both weed species and densities.
\end{abstract}

Keywords: Coffea arabica, weed density, interference, mineral nutrition, root.

\begin{abstract}
RESUMO - Este trabalho teve como objetivo avaliar os efeitos da competição de seis espécies de plantas daninhas sobre o crescimento, a concentração e o conteúdo de nutrientes no sistema radicular de plantas de café, cultivadas em casa de vegetação. Aos 30 dias após o transplantio das mudas de café, em vasos contendo $12 \mathrm{~L}$ de substrato e com área de $6,5 \mathrm{dm}^{2}$ na superficie do solo, fez-se o transplantio e, ou, a semeadura das espécies daninhas nesses vasos, em seis densidades $(0,1,2,3,4$ e 5 plantas por vaso). Os periodos de convivência, desde o transplantio ou emergência das plantas daninhas até a colheita das plantas, quando do florescimento das plantas daninhas, foram (em dias): 77 (Bidens pilosa), 180 (Commelina diffusa), 82 (Leonurus sibiricus), 68 (Nicandra physaloides), 148 (Richardia brasiliensis) e 133 (Sida rhombifolia). A massa seca do sistema radicular das plantas de café reduziu-se linearmente com o aumento da densidade de $B$. pilosa e de $S$. rhombifolia, com efeito mais pronunciado em $B$. pilosa. $C$. diffusa foi a única espécie que não reduziu o acúmulo de matéria seca no sistema radicular das plantas de café. $L$. sibiricus, $N$. physaloides e $R$. brasiliensis reduziram a massa seca da raiz do café em 75, 52 e $47 \%$, respectivamente, comparado ao tratamento livre de interferência, independentemente da densidade de plantas daninhas. Sob competição, apesar de apresentarem, no seu sistema radicular, concentrações
\end{abstract}

Recebido para publicação em 15.1.2007 2007 e na forma revisada em 25.10.2007.

2 Professor, Universidade Federal de Viçosa - Campus de Rio Paranaíba - Rod. BR 354, km 310, 38810-000, Rio Paranaíba-MG, <claudiopagotto@ufv.br>; ${ }^{3}$ Técnico de Nível Superior - Eng-Ao-Agro - EPAMIG-Fazenda Experimental de Pitangui, zona rural s/n, 35650-000, Pitangui-MG, <agmarterra@epamig.br>; ${ }^{4}$ Professor, Universidade Federal de Viçosa, Dep. de Fitotecnia, Av. PH Rolfs s/n, 36570-000, Viçosa-MG, <aasilva@ufv.br>. 
de macronutrientes (exceto para $\mathrm{P}$ ) inferiores àquelas do café, as plantas daninhas acumularam 4,2 (N), 12,3 (P), 4,3 (K), 5,5 (Ca), 7,6 (Mg) e 4,4 (S) vezes mais nutrientes nas raízes que as plantas de café. A concentração de nutrientes no café e nas plantas daninhas, assim como o grau de interferência dessas plantas, variaram fortemente com a espécie e densidade de planta daninha.

Palavras-chave: Coffea arabica, densidade de plantas daninhas, interferência, nutrição mineral, raiz.

\section{INTRODUCTION}

Competition (which represents the negative effect of the interaction) is the most studied types of interference among plants (Radosevich et al., 1996). Competition is a biological interaction occurring between at least two plants for limiting resources (mainly light, water and nutrients) (McNaughton \& Wolf, 1973). Resource limitations can be caused by unavailability, poor supply, or proximity to neighbouring plants, which ultimately can aggravate an already insufficient resource or create a deficiency where there was ample resource for a single individual (Radosevich et al., 1996). Actually, competition among weeds and crop affects both kinds of plants but weeds almost always have a deleterious effect on crops (Pitelli, 1985).

Among the several factors affecting competition degree, weedy period or the critical period of competition, and weed density are very important. The former addresses the period of time in the crop life cycle in which weed competition occurs and during which weeds should be controlled to prevent yield losses (Blanco \& Oliveira, 1978; Pitelli, 1985). The latter, representing the number of plants per unit of area, is also important in competition studies because of the relationship among crop yield, number of individuals, and resources in a given area (Blanco, 1972; Radosevich, 1987; Radosevich et al., 1996).

Coffee plantations, especially Coffea arabica L., are the most important crops in Brazil because of their high economic value and employment generated (Embrapa, 2004). In addition, Brazil ranks first in world coffee production and export. It has been estimated that there is a cultivated area of 2.305 million hectares with 5.814 billion coffee plants, and a production of 2.437 billion ton for $2006 / 2007$
(Conab, 2006). Coffee is a perennial crop grown in rows and may be in production up to 30 years. As a result of weed competition, coffee yield and quality are seriously decreased and weed control is one of the major cultural operations entailing high cost. Crop yield losses due to weed competition varied from 24\% (Moraima, et al., 2000) to $77 \%$ (Blanco et al., 1982). In addition to yield losses, several other harmful effects of weed competition on this crop are discussed elsewhere (Ronchi et al., 2001; Silva \& Ronchi, 2003; 2004) including weeds as an alternative host to the coffee strain of Xilella fastidiosa, that causes coffee leaf scorch (Leite Júnior \& Nunes, 2003; Lopes et al., 2003) and has a greater nutrient competitive potential than the coffee plants (Gallo et al., 1958; Ronchi et al., 2003).

The critical period of weed competition in coffee plantations has been determined in different conditions and locations of coffee production (Pereira \& Jones, 1954; Blanco et al., 1982; Friessleben et al., 1991; Moraima et al., 2000). Despite information available on the critical period of weed competition for this crop (at the reproductive stage), little is known about weed density, which is an important factor also affecting competition degree or intensity. Besides, just after transplanting in the field, young coffee plants seem to be highly sensitive to weed competition since weed control in the coffee rows is an agronomical practice usually applied by growers (Ronchi et al., 2001; Silva \& Ronchi, 2003, 2004). Nevertheless, the effects of weed competition on young coffee plants has been scarcely studied (Dias et al., 2004).

Several methods have been developed to study competition among different species of plants, and each of them constitutes a bioassay in that the response of a species is used to describe the interference of the other. 
The additive method is perhaps the most common approach used to study weed-crop relationships (Radosevich, 1987; Radosevich et al., 1996). In this method, two (or more) plant species are grown together, the crop and the weed. The density of one species, such as the crop, is usually kept constant, while the density of the other is varied. The species whose density is not changed, acts as a comparative indicator for the aggressiveness and competitiveness of the other species.

The objective of this study was to determine the competition effects of several weed species on the growth and both macronutrient concentration and content of coffee plant root systems, using the additive method. We hypothesized that the degree of weed competition with young coffee plants depends on weed species and densities. It also should be stressed that such study concerning growth and mineral nutrition aspects of coffee and weed root system under competition is unknown. The effects of these weed species on growth and nutrient contents, particularly in coffee plants shoots, has been published elsewhere (Ronchi et al. 2003; Ronchi e Silva, 2006).

\section{MATERIALS AND METHODS}

The experiment was conducted in a greenhouse in Viçosa $\left(20^{\circ} 45^{\prime} \mathrm{S}, 42^{\circ} 55^{\prime} \mathrm{W}\right.$; 650 asl), southeastern Brazil. Plants of Coffea arabica L. cv. Red Catuai, with five leaf pairs were transplanted into $12 \mathrm{~L}$ pots filled with a mixture of soil and organic matter $(3.5: 1, \mathrm{v} / \mathrm{v})$. The soil was a Yellowish Red Podzolic, 51\% clay, $\mathrm{pH} 4.9$, with an organic matter content of $2.95 \%$, and fertilized with $1.0 \mathrm{~kg} \mathrm{~m}^{-3}$ of $\mathrm{P}_{2} \mathrm{O}_{5}$ and $3.6 \mathrm{~kg} \mathrm{~m}^{-3}$ of dolomitic limestone. Fifteen and 60 days after transplanting, $3.0 \mathrm{~g} \mathrm{~N}$ were applied to each pot. Plants were irrigated daily with an automatic sprinkle system to maintain pot capacity and to prevent competition for water.

Six weed species (Table 1) commonly found in Brazilian coffee plantations (particularly Bidens pilosa, Commelina decumbens and Leonurus sibiricus; Ronchi et al., 2001) were grown separately in each pot (each weed species constituted an experiment), containing one coffee plant. Each weed species was established at six densities $(0,1,2,3,4$ and 5 plants per pot), with four replicates. Pots were distributed in the experimental area in a completely randomized design. Each plot was constituted by one pot, with a soil surface area of $0.065 \mathrm{~m}^{2}$. Thus, the range of weed density established in the pots relates to the density occurring in the fields approximately from zero up to 75 plants per square meter. Thirty days after coffee plants were transplanted, seed weeds (except the seedlings of Commelina diffusa, which were obtained from stem segment) were sown in the pot and the densities mentioned above were established by thinning them out after weed species emergence. The weedy periods (Table 1) for each species were considered as being the periods between weed emergence (or transplanting for C. diffusa) and their preflowering or flowering stage, when the experiments were discontinued. This stage was chosen because when the plants are about to initiate their reproductive phase, absorption and accumulation of nutrients (hence the competition) reach their maximum levels (Singh \& Singh, 1938; Pedrinho Júnior et al., 2004). At that time, both weed and coffee plant root systems were collected separately by washing using a fine mesh sieve until soil residues were removed. After that, they were washed with distilled water and oven-dried for $72 \mathrm{~h}$, at $70^{\circ} \mathrm{C}$ to determine root dry matter.

Dried root of both weeds and coffee plants were ground to a fine powder, homogenized and analyzed for quantification of $\mathrm{N}, \mathrm{P}, \mathrm{K}, \mathrm{Ca}, \mathrm{Mg}$ and S (Ronchi and Silva, 2006). Total root nutrient content was estimated as a product of nutrient concentration by total root dry matter per pot. Since it is quite difficult to eliminate micronutrient contamination from samples when soil was used as growth medium (Gallo et al., 1958), only macronutrients were analyzed.

The fitness of root dry matter data for analysis of variance was accomplished by graphic analysis of the residues, including the Hartley test to check for error homogeneity (Neter et al., 1990). Root dry matter of both coffee plant and weeds and its nutrient concentration were submitted to ANOVA and then to regression analysis. Thus, significant models were using weed species density as the independent variable. All the statistical

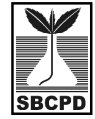


Table 1 - Weed species and weedy periods among them and the coffee plants

\begin{tabular}{|l|l|c|c|}
\hline \multicolumn{2}{|c|}{ Weed species } & $\begin{array}{c}\text { Weedy periods }{ }^{\underline{\underline{2}}} \\
\text { (days) }\end{array}$ \\
\hline Scientific names & \multicolumn{1}{|c|}{ Common names } & Code $^{1 /}$ & 77 \\
\hline Bidens pilosa & Beggar's ticks; cobber's pegs & BIDPI & 180 \\
\hline Leonmelina diffusa & Dayflower, hairy wandering jew & COMDI & 82 \\
\hline Nicandra physaloides & Lion's tail; chinese motherwort & LECSI & 68 \\
\hline Richardia brasilicnsis & Appe-of-Pcru; shoo-fly & NICPH & 148 \\
\hline Sida rhombifolia & Brazillian pusley, Brazil pusley & SIDRH & 133 \\
\hline
\end{tabular}

${ }^{1}$ Source: Lorenzi (2000); ${ }^{2}$ Weedy periods were considered as being the periods between weed emergence (or transplanting for $C$. diffusa) and their preflowering or flowering stage.

analyses were performed using the SAEG System version 8.0 (SAEG, 1999).

\section{RESULTS AND DISCUSSION}

Root system dry matter of both $B$. pilosa and $S$. rhombifolia linearly increased with increasing density; however, the linear reduction in the root system dry matter of coffee plants induced by $B$. pilosa was much higher than that induced by $S$. rhombifolia (Table 2). For example, from one to five plants of B. pilosa per pot a decrease of $20 \%$ in coffee root system dry matter was observed to each weed individual added to the pot (Table 2). Similar results were also observed in coffee plant shoot dry matter (Ronchi et al. 2003; Ronchi e Silva, 2006).

Commelina diffusa was the only weed species whose increasing density in the pots did not decrease coffee root system dry matter (Table 2), although such effect on coffee shoot dry matter was dramatic (Ronchi and Silva, 2006). In any case, C. diffusa root system dry matter did not rise as its density increased (Table 2). It must be emphasized that weeds such as Commelina spp. (C. Benghalensis and C. diffusa) and B. pilosa are widely dispersed in Brazilian coffee fields (Blanco et al., 1982; Ronchi et al., 2001).

Similar negative effects on coffee dry matter accumulation was observed due to competition of different densities of $L$. sibiricus, $N$. physaloides and $R$. brasiliensis: coffee dry matter decreases quickly due to the presence of only one type of weed per pot, but no additional (or only slight) reduction in coffee dry matter was observed as weed densities increased (according to a Rsquared model; Table 2). Regardless of the presence of one or five plants of $L$. sibiricus, $N$. physaloides and $R$. brasiliensis, coffee dry matter reduced by 75,52 and $47 \%$, respectively, compared to weedfree treatment (Table 2). In any case, since $C$. diffusa, $R$. brasiliensis and $L$. sibiricus did not increase with increasing density, no significative effect of these weed densities on root dry matter accumulation was observed (Table 2).

There was a significant and negative effect of weed density on macronutrient concentration in the root system of the coffee plants, except for $\mathrm{P}$ and $\mathrm{Mg}$ for B. pilosa, $\mathrm{P}, \mathrm{Mg}$ and $\mathrm{S}$ for $C$. diffusa and $\mathrm{P}$ for $R$. brasiliensis (Table 3). Such a negative effect was linear $(\hat{Y}=\mathrm{a}-\mathrm{bX})$ or Rsquared $\left(\hat{Y}=\mathrm{a}-\mathrm{bX}^{1 / 2}+\mathrm{cX}\right)$ depending on both nutrient and weed considered (Table 3). According to the former regression model, nutrient concentration in the coffee plant reduced linearly as weed density increased (e.g., B. pilosa; P; $\hat{Y}=0.203$ - 0.011X; Table 3); in the latter, a marked reduction on nutrient concentration was expected to occur mainly at low weed density, with a slight effect under high densities (e.g. B. pilosa; $\mathrm{N} ; \hat{Y}=$ $2.769-0.808 \mathrm{X}^{1 / 2}+0.083 \mathrm{X}$; Table 3).

Using of Table 3 regression equations and considering weed density of one plant per pot, B. pilosa, C. diffusa, L. sibiricus, $N$. physaloides, $R$. brasiliensis and $S$. rhombifolia reduced $\mathrm{N}$ concentration in roots by $26,38,60,56,32$ and $41 \%$; $\mathrm{K}$ concentration by $24,57,51,53,6$ and $32 \%$, and $\mathrm{Ca}$ concentration by $9,4,45,35,4$ and 
Table 2 - Dry matter accumulation ( $\left.\mathrm{g} \mathrm{pot}^{-1}\right)$ in both coffee and weed root system related to weed species density (plants per pot)

\begin{tabular}{|c|c|c|c|}
\hline \multirow{2}{*}{ Weed species } & Equation & \multirow{2}{*}{$\mathrm{R}^{2}$} & \multirow{2}{*}{$\mathrm{CV}(\%)$} \\
\hline & Coffee & & \\
\hline Bidens pilosa & $\hat{Y}=5.491-0.773 * * X$ & 94.76 & 29.49 \\
\hline Commelina diffusa & $\hat{Y}=\bar{Y}=16.540$ & - & 39.52 \\
\hline Leonurus sibiricus & $\hat{Y}=7.623-7.323 * * \sqrt{X}+2.194 * * X$ & 96.10 & 46.16 \\
\hline Nicandra physaloides & $\hat{Y}=6.597-4.441 * * \sqrt{X}+1.333 * * X$ & 97.09 & 25.01 \\
\hline Richardia brasiliensis & $\hat{Y}=14.392-8.428 * \sqrt{X}+2.472^{\mathrm{ns}} X$ & 78.73 & 40.96 \\
\hline \multirow[t]{2}{*}{ Sida rhombifolia } & $\hat{Y}=8.077-0.012 * X$ & 63.42 & 63.02 \\
\hline & Weed & & \\
\hline Bidens pilosa & $\hat{Y}=1.938+4.572 * * X$ & 89.00 & 41.27 \\
\hline Commelina diffusa & $\hat{Y}=\bar{Y}=10.551$ & - & 16.38 \\
\hline Leonurus sibiricus & $\hat{Y}=\bar{Y}=33.040$ & - & 28.01 \\
\hline Nicandra physaloides & $\hat{Y}=23.953+54.644 * * \sqrt{X}-14.819 * * X$ & 94.38 & 14.67 \\
\hline Richardia brasiliensis & $\hat{Y}=Y=17.052$ & - & 21.61 \\
\hline Sida rhombifolia & $\hat{Y}=7.675+6.059 * * X$ & 90.46 & 23.69 \\
\hline
\end{tabular}

$F$-test at ${ }^{* *} P<0.05 ;{ }^{*} P<0.01$; and ${ }^{\mathrm{ns}} P>0.05$ was applied to equation parameters. $\mathrm{R}^{2}=$ Rsquare. $\mathrm{CV}=$ coefficient of variation.

$11 \%$, respectively, as compared to weed-free treatment. In general, $\mathrm{N}$ and $\mathrm{K}$ concentrations were more affected by weeds than $\mathrm{Ca}$ concentration. $\mathrm{N}$ concentration was more affected by $L$. sibiricus, $\mathrm{K}$ by $C$. diffusa and $\mathrm{Ca}$ by $N$. physaloides. All togheter these data indicate that nutrient concentrations in the roots of coffee plants are differently affected depending on weed species and nutrient.

For almost all the weeds and nutrients, there was no effect of increasing weed species density on its root system macronutrient concentration. Table 4 shows the mean values $(\hat{Y}=\bar{Y})$ for each weed and nutrient, regardless of weed density. However, root concentration of $\mathrm{P}, \mathrm{K}$ and $\mathrm{Mg}$ for $\mathrm{B}$. pilosa, $\mathrm{P}$ and $\mathrm{Mg}$ for C. diffusa, $\mathrm{N}$ for $N$. physaloides and $\mathrm{N}, \mathrm{P}$ and $\mathrm{Ca}$ for S. rhombifolia markedly decreased (according to a linear or Rsquare models) with increasing weed density (Table 4). Only for $R$. brasiliensis, $\mathrm{Mg}$ and $\mathrm{S}$ concentrations linearly increased with increasing weed density (Table 4).

Considering each nutrient separately, there was a great difference in nutrient concentration among weed species, which allowed to arranged them into three recognizable categories, the distinguishing feature of each of the classes being the presence of higher $(\mathrm{H})$, medium $(\mathrm{M})$ or lower (L) concentration of a particular nutrient in the root system dry matter: $\mathrm{N}$ : $(\mathrm{H}-0.87 \%)$ B. pilosa, C. diffusa, N. physaloides; (M $0.59 \%)$ L. sibiricus and S. rhombifolia; (L $0.43 \%) R$. brasiliensis; $\mathrm{P}(\mathrm{H}-0.48 \%)$ N. physaloides; (M - 0.32\%) B. pilosa, C. diffusa and S. rhombifolia; (L - 0.15\%) $L$. sibiricus and $R$. brasiliensis; $\mathrm{K}(\mathrm{H}-1.10 \%)$ $N$. physaloides and S. rhombifolia; (M-0.91\%) C. diffusa $(\mathrm{L}-0.76 \%) B$. pilosa, L. sibiricusand $R$. brasiliensis; $\mathrm{Ca}(\mathrm{H}-0.67 \%) B$. pilosa, C. diffusa, $N$. physaloidesand $R$. brasiliensis; (M - 0.51\%) S. rhombifolia; (L - 0.32\%) L. sibiricus; $\mathrm{Mg}(\mathrm{H}-0.58 \%) N$. physaloides; (M - 0.32\%) B. pilosa, C. diffusa, L. sibiricus and S. rhombifolia; (L-0.18\%) R. brasiliensis, S (H - $0.26 \%)$ B. pilosa, C. diffusa and $N$. physaloides; (M-0.19\%) S. rhombifolia; (L $0.11 \%)$ L. sibiricus and $R$. brasiliensis (Data not shown). All together, these data showed that macronutrient concentration in the root system dry matter was higher in 
Table 3 - Macronutrient concentration (\%) in coffee root system dry matter related to weed species density (plants per pot)

\begin{tabular}{|c|c|c|c|c|}
\hline Weed species & Nutrient & Equation & $\mathrm{R}^{2}$ & $\mathrm{CV}(\%)$ \\
\hline \multirow{6}{*}{ Bidens pilosa } & $\mathrm{N}$ & $\hat{Y}=2.769-0.808^{*} \sqrt{X}+0.083^{\mathrm{ns}} X$ & 92.40 & 17.30 \\
\hline & $\mathrm{P}$ & $\hat{Y}=0.203-0.011 * * X$ & 60.00 & 14.22 \\
\hline & $\mathrm{K}$ & $\hat{Y}-2.956-0.779 * X+0.083^{* *} X^{2}$ & 99.48 & 22.77 \\
\hline & $\mathrm{Ca}$ & $\hat{Y}=1.372-0.119^{* *} X$ & 76.00 & 26.78 \\
\hline & $\mathrm{Mg}$ & $\hat{Y}=\bar{Y}=0.552$ & - & 35.68 \\
\hline & $\mathrm{S}$ & $\hat{Y}=0.548-0.049^{* *} X$ & 85.82 & 26.32 \\
\hline \multirow{6}{*}{ Commelina diffusa } & $\mathrm{N}$ & $\hat{Y}=1.937-1.074 * * \sqrt{X}+0.337 * * X$ & 98.84 & 20.32 \\
\hline & $\mathrm{P}$ & $\hat{Y}-\bar{Y}-0.183$ & - & 29.18 \\
\hline & $\mathrm{K}$ & $\hat{Y}=2.886-2.374 * * \sqrt{X}+0.726^{* * X}$ & 99.03 & 12.19 \\
\hline & $\mathrm{Ca}$ & $\hat{Y}=0.869-3.969 * * X$ & 51.23 & 10.46 \\
\hline & $\mathrm{Mg}$ & $\hat{Y}=\bar{Y}=0.722$ & - & 15.45 \\
\hline & $\mathrm{S}$ & $\hat{Y}=\bar{Y}=0.491$ & - & 21.30 \\
\hline \multirow{6}{*}{ Leonurus sibiricus } & $\mathrm{N}$ & $\hat{Y}-3.071-2.512 * * \sqrt{ } X+0.681 * * X$ & 97.63 & 24.88 \\
\hline & $\mathrm{P}$ & $\hat{Y}=0.244-0.139 * * \sqrt{X}+0.038 * * X$ & 97.23 & 16.62 \\
\hline & $\mathrm{K}$ & $\hat{Y}=3.325-2.221^{* *} \sqrt{X}+0.527^{* *} X$ & 96.21 & 25.67 \\
\hline & $\mathrm{Ca}$ & $\hat{Y}=1.151-0.693 * * \sqrt{X}+0.171 * * X$ & 94.44 & 19.48 \\
\hline & $\mathrm{Mg}$ & $\hat{Y}=0.712-0.512 * * \sqrt{X}+0.132 * * X$ & 95.61 & 21.43 \\
\hline & S & $\hat{Y}=0.515-0.259 * * \sqrt{X}+0.052 * * X$ & 92.85 & 15.15 \\
\hline \multirow{6}{*}{ Nicandra physaloides } & $\mathrm{N}$ & $\hat{Y}=3.369-2.679 * * \sqrt{X}+0.792 * * X$ & 97.29 & 8.67 \\
\hline & $\mathrm{P}$ & $\hat{Y}=0.276-0.169 * * \sqrt{X}+4.948 * * X$ & 94.20 & 13.08 \\
\hline & $\mathrm{K}$ & $\hat{Y}=3.273-2.503 * * \sqrt{X}+0.758 * * X$ & 97.23 & 10.88 \\
\hline & $\mathrm{Ca}$ & $\hat{Y}=1.206-0.555 * * \sqrt{X}+0.127 * X$ & 93.52 & 17.72 \\
\hline & $\mathrm{Mg}$ & $\hat{Y}=0.778-0.400^{* *} \sqrt{X}+0.102^{* *} X$ & 92.25 & 14.19 \\
\hline & $S$ & $\hat{Y}=0.475-0.245^{* *} \sqrt{X}+0.076^{*} X$ & 88.00 & 23.01 \\
\hline \multirow{6}{*}{ Richardia brasiliensis } & $\mathrm{N}$ & $\hat{Y}=2.328-0.974 * * \sqrt{X}+0.222 * * X$ & 89.00 & 12.61 \\
\hline & $\mathrm{P}$ & $\hat{Y}=\bar{Y}=0.197$ & - & 27.49 \\
\hline & $\mathrm{K}$ & $\hat{Y}=2.782-0.179 * * X$ & 65.65 & 17.38 \\
\hline & $\mathrm{Ca}$ & $\hat{Y}=0.880-0.035^{*} X$ & 50.62 & 16.61 \\
\hline & $\mathrm{Mg}$ & $\hat{Y}=0.599-0.041 * * X$ & 62.73 & 20.88 \\
\hline & $\mathrm{S}$ & $\hat{Y}=0.478-0.028 * X$ & 82.12 & 25.99 \\
\hline \multirow{6}{*}{ Sida rhombifolia } & $\mathrm{N}$ & $\hat{Y}=2.600-1.300 * * \sqrt{X}+0.222 * X$ & 98.65 & 18.19 \\
\hline & $\mathrm{P}$ & $\hat{Y}=0.205-0.018^{* *} X$ & 87.52 & 24.40 \\
\hline & $\mathrm{K}$ & $\hat{Y}=2.828-1.159 * * \sqrt{ } X+0.247^{\mathrm{ns}} X$ & 97.70 & 23.45 \\
\hline & $\mathrm{Ca}$ & $\hat{Y}=0.933-0.106^{* * *} X$ & 85.86 & 27.58 \\
\hline & $\mathrm{Mg}$ & $\hat{Y}=0.505-0.049^{* * *} X$ & 81.79 & 32.89 \\
\hline & $\mathrm{S}$ & $\hat{Y}=0.443-0.026^{* *} X$ & 59.24 & 25.21 \\
\hline
\end{tabular}

Statistic as in Table 1. 
Growth and nutrient concentration in coffee root system under ...

Table 4 - Macronutrient concentration (\%) in weed root system dry matter related to weed species density (plants per pot)

\begin{tabular}{|c|c|c|c|c|}
\hline Weed species & Nutrient & Equation & $\mathrm{R}^{2}$ & $\mathrm{CV}(\%)$ \\
\hline \multirow{6}{*}{ Bidens pilosa } & $\mathrm{N}$ & $\hat{Y}=\bar{Y}=0.834$ & - & 18.75 \\
\hline & $\mathrm{P}$ & $\hat{Y}=0.248-0.024^{*} X$ & 69.31 & 18.06 \\
\hline & $\mathrm{K}$ & $\hat{Y}=1.111-0.115^{*} X$ & 81.63 & 33.04 \\
\hline & $\mathrm{Ca}$ & $\hat{Y}=\bar{Y}=0.642$ & - & 19.56 \\
\hline & $\mathrm{Mg}$ & $\hat{Y}=\left(0.147-\left(0.062^{* *} X\right.\right.$ & 81.45 & 19.06 \\
\hline & $\mathrm{S}$ & $\hat{Y}=\bar{Y}=0.255$ & - & 24.82 \\
\hline \multirow{6}{*}{ Commelina diffusa } & $\mathrm{N}$ & $\hat{Y}=Y=0.924$ & - & 16.38 \\
\hline & $\mathrm{P}$ & $\hat{Y}=0.037-0.445^{\mathrm{ns}} \sqrt{X}-0.160 * X$ & 82.65 & 15.94 \\
\hline & $\mathrm{K}$ & $\hat{Y}=\bar{Y}=0.915$ & - & 14.49 \\
\hline & $\mathrm{Ca}$ & $\hat{Y}=\bar{Y}=0.625$ & - & 22.57 \\
\hline & $\mathrm{Mg}$ & $\hat{Y}--0.381-1.178 * * \sqrt{X}-0.407 * * X$ & 88.43 & 17.19 \\
\hline & $\mathrm{S}$ & $\hat{Y}=\bar{Y}=0.248$ & - & 19.63 \\
\hline \multirow{6}{*}{ Leonurus sibiricus } & $\mathrm{N}$ & $\hat{Y}=\bar{Y}=0.539$ & - & 24.44 \\
\hline & $\mathrm{P}$ & $\hat{Y}=\bar{Y}=0.106$ & - & 25.70 \\
\hline & $\mathrm{K}$ & $\hat{Y}=\bar{Y}=0.678$ & - & 40.19 \\
\hline & $\mathrm{Ca}$ & $\hat{Y}=\bar{Y}=0.332$ & - & 15.23 \\
\hline & $\mathrm{Mg}$ & $\hat{Y}=\bar{Y}=0.279$ & - & 27.14 \\
\hline & $\mathrm{S}$ & $\hat{Y}=\bar{Y}=0.113$ & - & 31.73 \\
\hline \multirow{6}{*}{$\begin{array}{c}\text { Nicandra } \\
\text { physaloides }\end{array}$} & $\mathrm{N}$ & $\hat{Y}=1.006-0.047 * X$ & 62.31 & 12.73 \\
\hline & $\mathrm{P}$ & $\hat{Y}=\bar{Y}=0.486$ & - & 13.24 \\
\hline & $\mathrm{K}$ & $\hat{Y}=\bar{Y}=1.079$ & - & 35.79 \\
\hline & $\mathrm{Ca}$ & $\hat{Y}=\bar{Y}=0.717$ & - & 12.11 \\
\hline & $\mathrm{Mg}$ & $\hat{Y}=\bar{Y}=0.583$ & - & 19.51 \\
\hline & $\mathrm{S}$ & $\hat{Y}=\bar{Y}=0.296$ & - & 31.14 \\
\hline \multirow{6}{*}{$\begin{array}{c}\text { Richardia } \\
\text { brasiliensis }\end{array}$} & $\mathrm{N}$ & $\hat{Y}=\bar{Y}=0.437$ & - & 20.85 \\
\hline & $\mathrm{P}$ & $\hat{Y}=\bar{Y}=0.207$ & - & 19.70 \\
\hline & $\mathrm{K}$ & $\hat{Y}=\bar{Y}=0.743$ & - & 16.08 \\
\hline & $\mathrm{Ca}$ & $\hat{Y}=\bar{Y}=0.700$ & - & 19.81 \\
\hline & $\mathrm{Mg}$ & $\hat{Y}=0.154+0.009 * X$ & 82.75 & 10.79 \\
\hline & $\mathrm{S}$ & $\hat{Y}=0.055+0.009 * * X$ & 92.84 & 11.96 \\
\hline \multirow{6}{*}{ Sida rhombifolia } & $\mathrm{N}$ & $\hat{Y}=0.743-0.064 * X$ & 81.29 & 23.00 \\
\hline & $\mathrm{P}$ & $\hat{Y}=0.429-0.032 * * X$ & 77.49 & 15.34 \\
\hline & $\mathrm{K}$ & $\hat{Y}=\bar{Y}=1.136$ & - & 18.90 \\
\hline & $\mathrm{Ca}$ & $\hat{Y}=0.664-0.048 * * X$ & 88.93 & 17.83 \\
\hline & $\mathrm{Mg}$ & $\hat{Y}=\bar{Y}=0.313$ & - & 27.01 \\
\hline & $\mathrm{S}$ & $\hat{Y}=\bar{Y}=0.198$ & - & 29.59 \\
\hline
\end{tabular}

Statistic as in Table 1. 
$N$. physaloides, lower in both $L$. sibiricus and $R$. brasiliensis and with intermediate values for other species herein investigated.

Weeds have been reported to contain a much higher percentage of nutrients than the common crop plants or as being a better nutrient accumulators than crops (Singh \& Singh, 1938; Gallo et al., 1958; Qasem, 1992; Ronchi et al., 2003), thus highlighting a good indicator of their greater competitive abilities. However, such general conclusion must be interpreted with caution because it is not consistent for all crop, weed, and mineral interactions (Qasem, 1992). Moreover, the apparent higher nutrient concentration in weeds than in crops was exclusively based on shoot dry matter data, and a different pattern may occur when root systems are considered. Contrary to their content in shoots, N, K, Ca and $\mathrm{Mg}$ percentage in roots of most weed species was lower than that of bean crop and the percentage of $\mathrm{N}, \mathrm{Ca}$ and $\mathrm{Mg}$ of many weed species was lower that in tomato roots (Qasem, 1992). Other works have also reported lower root concentrations of nutrients in weed species than in crop plants (Kolar et al., 1980). Corroborating such information, comparisons of the results shown in Tables 3 and 4 revealed that under competition, the concentrations of $\mathrm{N}, \mathrm{K}, \mathrm{Ca}, \mathrm{Mg}$ and $\mathrm{S}$ were $40 \%, 40 \%, 22 \%, 24 \%$ and $44 \%$, respectively, lowe $r$ in weeds (considering all weeds together) than in the coffee root system (data not shown). Nutrient content rather than nutrient concentration, is a better indicator of weed competition (Pitelli, 1985), since the former considers dry matter production for weed communities. Thus, even showing lower macronutrient concentration in roots (except for P), weeds herein investigated extracted (accumulated) a total average of $4.2(\mathrm{~N}), 12.3(\mathrm{P}), 4.3(\mathrm{~K}), 5.5$ $(\mathrm{Ca}), 7.6(\mathrm{Mg})$ and $4.4(\mathrm{~S})$ times more nutrients than the coffee plant root system (data not shown), at the and of a specific weedy period. These are total mean values and obviously large variations were detected among weed species, weed densities and mineral elements.

Taking in to account that interference among neighbouring plants occurs after a specific weed density had been reached (Aldrich, 1987), in addition to crop-weed competition, intraspecific competition among individuals of the same weed species certainly had also occurred, mainly at higher densities. Moreover, the effect of weed competition could have been overestimated due to reduced pot size. However, it is usually observed in young field coffee plantations that weed densities are much higher than those studied here, and could reach a high degree of competition as that reported here. Hence, on the grounds of the present experimental conditions, it is highly recommended that weeds be controlled within crop rows to prevent weed competition for nutrients. This would decrease initial crop growth, delaying its establishment and the time taken by them to reach maturity, probably reducing also their bearing capacity. Further research on weed competition against young coffee plants under field conditions may be of major importance to improve management of coffee crops.

\section{LITERATURE CITED}

ALDRICH, R. J. Predicting crop yield reduction s from weeds. Weed Technol., v. 1,p. 199-206, 1987.

BLANCO, H. G. A importância dos estudos ecológicos nos programas de controle das plantas daninhas. Biológico, v. 38, n. 10 , p. $343-350,1972$.

BLANCO, H. G.; OLIVEIRA, D. A. Estudos dos efeitos da época de controle do mato sobre a produção de citros e a composição da flora daninha. Biológico, v. 45, n. 1, p. 2536, 1978.

BLANCO, H. G.; OLIVEIRA, D. A.; PUPO, E. I. H. Período de competição de uma comunidade natural de mato em uma cultura de café em formação. Biológico, v. 48, n. 1, p. 9-20, 1982.

COMPANHIA NACIONAL DE ABASTECIMENTO CONAB. Segundo levantamento safra 2006/2007: café beneficiado. Disponível em: (http://www.conab.gov.br/ download/Safra/Safracafe.pdf). Acesso em: 26 de julio de 2006.

DIAS, G. F. S.; ALVES, P. L. C. A.; DIAS, T. C. S. Brachiaria decumbens suppresses the initial growth of Coffea arabica. Sci. Agric., v. 61, n. 6, p. 579-583, 2004.

EMPRESA BRASILEIRA DE PESQUISA AGROPECUÁRIA - EMBRAPA. Café: histórico. Disponível em: (http://www.embrapa.br/cafe/historico.htm). Acesso em: 29 de fevereiro 2004.

FRIESSLEBEN, U.; POHLAN, J.; FRANKI, G. The response of Coffea arabica L. to weed competition. Café, Cacao The, v. 35, n. 1, p. 15-20, 1991. 
GALLO. J. R. et al. Absorção de nutrientes pelas ervas daninhas e sua competição com o cafeeiro. B. Inst. Agron., v. 104, p. 1-13, 1958.

KOLAR, J. S.; BAINS, D. S.; GILL, G. S. Studies of competitive ability of wheat and Chenopodium album L. Indian J. Ecol., v. 7, p. 308-31 0, 1980.

LEITE Jr., R. P.; NUNES, L. M. Avanços nas pesquisas sobre Xylella fastidiosa do café no Brasil. In: ZAMBOLIM, L. (Ed.) Produção integrada de café. Viçosa, MG: Universidade Federal de Viçosa, 2003. p. 87-101.

LOPES, S. A. et al. Weeds as alternative hosts of the citrus, coffee, and plum strains of Xylella fastidiosa in Brazil. Plant Disease, v. 87, p. 544-549, 2003.

LORENZI, H. Manual de identificação e controle de plantas daninhas: plantio direto e convencional. 5. ed. Nova Odessa: Plantarum, 2000. 384 p.

McNAUGHTON, S. J.; WOLF, L. L. General ecology . New York: Holt, Rinchart \& Winston, 1973. 710 p.

MORAIMA, G. S. et al. A contribution to determine critical levels of weed interference in coffee crops of Monagas state, Venezuela. Bioagro, v. 12, n. 3, p. 63-70, 2000.

NETER. J.; WASSERMAN, V.; KUTNER, M. H. Applied linear statistical models: regression, analysis of variance and experimental designs. Homewood: Richard A. Irwin, 1990. $842 \mathrm{p}$.

PEDRINHO Jr., A. F. F.; BIANCO, S.; PITELLI, R. A. Acúmulo de massa seca e macronutrientes por plantas de Glycine max e Richardia brasiliensis. Planta Daninha, v. 22, n. 1, p. 53-61, 2004.

PEREIRA, H. C.; JONES, P. A. A tillage study in Kenya Coffee. Part I: The effects of tillage practices on coffee yields. Emp. J. Exp. Agric., v. 22, n. 87, p. 231-240, 1954.
PITELLI, R. A. Interferência de plantas daninhas em culturas agrícolas. Informe Agropec., v. 120, n. 11, p. 16-27, 1985.

QASEM, J. R. Nutrient accumulation by weeds and their associated vegetable crops. J. Hortic. Sci., v. 67, n. 2, p. 189-195, 1992.

RADOSEVICH, S. R. Methods to study interactions among crops and weeds. Weed Technol., v. 1, p. 190-198, 1987.

RADOSEVICH, S. R.; HOLT, J.; GHERSA, C. Weed ecology: implication for managements. New York: John Wiley \& Sons, Inc., 1996. 589 p.

RONCHI, C. P. et al. Acúmulo de nutrientes pelo cafeeiro sob interferência de plantas daninhas. Planta Daninha, v. 21 , n. 2, p. 219-227, 2003.

RONCHI, C. P.; SILVA, A. A. Effects of weed species competition on the growth of young coffee plants. Planta Daninha, v. 24, n. 2, p. 415-423, 2006.

RONCHI, C. P.; SILVA, A. A.; FERREIRA, L. R. Manejo de plantas daninhas em lavouras de café. Viçosa, $\mathrm{MG}$ : Suprema Gráfica \& Editora, Viçosa, 2001. 94 p.

SILVA, A. A.; RONCHI, C. P. Avanços nas pesquisas sobre o controle de plantas daninhas na cultura do café. In: ZAMBOLIM, L. (Ed.) Produção integrada de café. Viçosa, MG: Universidade Federal de Viçosa, 2003. p. 103-132.

SILVA, A. A.; RONCHI, C. P. Manejo e controle de plantas daninhas em café. In: VARGAS, L.; ROMAN, E. S. (Orgs.). Manual de manejo e controle de plantas daninhas. Bento Gonçalves: Embrapa Uva/Vinho, 2004. p. 337-396.

SINGH, B. N.; SINGH, L. B. Relative absorption of nutrients by weeds of arable land. Soil Sci., v. 47, p. 227235, 1938.

SISTEMA PARA ANÁLISES ESTATÍSTICAS - SAEG. version 8.0. Viçosa, MG: Fundação Arthur Bernardes, 1999. 